\title{
Has God Been and Gone?
}

\author{
Patrick Hutchings ${ }^{1}$
}

Accepted: 26 March 2021 / Published online: 2 July 2021

(c) The Author(s), under exclusive licence to Springer Nature B.V. 2021

Could anyone live without God? The pragmatic answer is, 'Yes'. If we compare the Australian census figures for 2006 and 2016, we find that in 2006, 19\% filled in the question 'what religion', 'none': in 2016, 30\% recorded, 'no religion'. How could this be so? The Jansenist Blaise Pascal (1623-1662) ${ }^{1}$ would have said this sort of thing, 'By diverting their minds from Godly matters'. Diversion is offered by the national religions of sport and unnecessary consumption. Australia was founded in 1788 as a place of imprisonment, the American thirteen colonies having in 1776 revolted against England and George III, the fledging USA was no longer open as a dumping ground for English criminals. So, under the poisonous fiction that Terra Australis was Terra Nullius - nobody's place- the Continent was open as a prison, and a place in which to practice European agriculture, 'Land of Drought and Flood'2 notwithstanding. The treatment of the Aboriginal owners of the land has been shameful, and shameless: the usual Colonialist pattern.

As a country in 2020, we are multicultural: good. But we are a petty bourgeois society, with the usual gratin $^{3}$ of undeserving rich. The Commonwealth exports iron, coal, and natural gas. Our third greatest export is University Degrees. Before COVID-19, Australia attracted Chinese, Indian, and other foreign students: this inward educational traffic may well not continue. Our corporatized university 'industry' may go bust, and help from a philistine and 'economic rationalist' federal

\footnotetext{
1 Blaise Pascal (1623-1662) a semi-Jansenist thinker one of whose Pensées is quoted later on in this paper. He was a great mathematician. He had a religious experience. It is recognized by some as genuine, and put down by others to his fontanelles continuing to grow too long after infancy. He suffered greatly from headaches.

${ }^{2}$ My Country by Dorothea Mackellar (1885-1958) 'I love a sunburnt country/Land of drought and flood...'. It is a good poem, but tarnished by climate change deniers as a 'proof' that the recent-2019unprecedented bushfires and floods are just more of the same. There is a now disused Prime Minister who said 'Climate change is crap', and forbade civil servants' using the words 'climate change'. At present, he has a job in the UK where one would like him to stay.

${ }^{3}$ Gratin, French for 'the top crust', i.e. the very well off. Literally, 'gratin' is the top layer of a dish of thinly sliced potatoes dressed in butter and olive oil, baked in the oven-pommes Anna. The gratin is made of two kinds of hard cheese grated and mixed with a few breadcrumbs. The gratin is the tastiest part of the dish-everyone wants more than their fair share of it.
}

Patrick Hutchings

hthehutchings@gmail.com

1 University of Melbourne, Melbourne, Australia 
government is not to be expected, this even although the virus has forced it into Keynesian policies. Indeed, financial cuts to higher education are in the offing: Many MPs got their degrees when universities were offering instruction gratis. University staff-tutors and so on-are largely casual and so do not get the 'Economic Support Payment', Keynesian, money that other workers do. How then can junior academics carry on research and publication? How can they evolve into future professors?

Living without God here is a cakewalk: Mammon, if not worshipped, is still highly thought of.

\section{The Human Predicament}

\section{How Might We Cope-God Absent?}

The American novelist Saul Bellow's Herzog ${ }^{4}$ has the slightly deranged Herzog writing letters — which he never sends - to Heidegger... 'Dear Herr Doctor Professor you write of "the fall into the quotidian", where were you when it happened?' The only possible answer is, 'Directly beside it, and I got sucked in.' The cosmologist Brian Cox sets us the question, 'How can we live meaningful lives in an essentially meaningless universe?' 'With difficulty!' We must remember Sartre on 'projects': Since each of us carries meaning, as a function of our rationality with us, we need to find a rational ethic, and a rational politic. The first seems reachable. The second, in 2020, may well be beyond our grasp.

First then to an ethic. To a 'Western' philosopher, there is an obvious/ 'obvious' pair: (1) Utilitarianism, 'The greatest happiness of the greatest number', and (2) Kant's Categorical Imperative. Unfortunately, one collapses into the other in a disquieting way. Kant's, 'Act only on that principle/maxim that you could will to become an universal law', turns out to be no more than a way of ruling out non-Utilitarian maxims. ${ }^{6}$ The Categorical Imperative, Kant intended to be neatly — and purely_logical. His best example was, making false promises. If everybody failed to keep their promise, reneged on their contracts, etc., then the institution of promising would fall apart. The Categorical Imperative ceases to work in other cases. From being - nearly_purely logical, the Categorical Imperative eventually came to depend on the fairly contingent: what people would put up with. Certain migrant communities in Australia have a custom of female circumcision. Here, it is a criminal offence — as it ought to be-everywhere. And, of course, Utilitarianism ${ }^{7}$ comes $^{-}$

\footnotetext{
${ }^{4}$ Herzog, by Saul Bellow, London, Weidenfield and Nicholson, 1964: [USA ed. 1961] p. 49.

5 The New Yorker for June 1, 2020, p. 25 has a cartoon by L. Fink, 'The Eighth Day', of God sitting quite alone on His cloud-supported throne, and with a very glum look on his face, a voice comes up from below, 'But what does it all mean?' If you have a copy of the journal, see also James Wood's, 'In from the cold: a Hungarian essayist struggles against Enlightenment', pp. 64-67. God and Hegel appear in this piece.

6 See my Kant on Absolute Value, London, Allen and Unwin, Detroit, Wayne State University Press, 1972, pp. 234ff.

7 The New Zealand of my youth-I went up to University in the late 1940s-was a virtually homogenous social democracy: Though the Māori had not yet all that the Treaty of Waitangi had promised. My late Father who rose to a distinguished rank in the Health Department had one and one only philosophy book, J.S. Mill's Utilitarianism, slim and bound in buckram. He read Marx, 'Splendid Economist, but where does the spooky stuff come from?' 'Hegel', 'Did he write much?', 'Shelves full', 'Oh'.
} 
full of examples of consequences, which some people would not put up with. The 'greatest happiness of the greatest number' might lead governments to treat minorities unjustly; unless nuanced, the principle can lead to bad consequences. So the Categorical Imperative has to find what is - positively-congenial and useful, and what is not. We need to try to fill out a 'western' ethic with ideas from Gandhi, Confucius, and Zoroaster: indeed, most Prophets. Should we, even then, end up in a logical cramp, the 'fall into the quotidian' may prove as unresolvable as is the Fall of Adam and Eve. Of that, more later on. However whether we believe in God or not, we all live in a broken world. Now the second thing we need: Good Politics.

\section{The Great Republic and Its Constitution: Trumped!}

\section{The Decline of Politics?}

Kellyanne Conway has a place in the future History of The Decline of the West. When Trump boasted, falsely, 'There were more people at my Inauguration than Obama's', aerial photos showed rows and rows of empty seats at Trump's swearing in. Conway defended The Donald, 'He was offering an alternative fact'. The expression 'alternative fact' makes no sense. It does to postmodernists, it seems. In her The Death of Truth ${ }^{8}$ Michiko Kakutani argues_convincingly_for PoMo's dovetailing neatly into a former reality show's presenter getting elected to the Presidency of the USA. Trump's base won't have heard of PoMo: their real grievances, loss of jobs, etc. had them voting for a zany, a demagogue with a small vocabulary and strangulated syntax. What PoMo can do is give a gloss of respectability to the endless inarticulate tweets, which now rank as Presidential policy statements (p. 100), despite their contradicting other tweets (p. 95). And being full of personal insults and blah blah they are nevertheless taken as serious and important. The base just loves the superhot-air twaddle. Umberto Eco writes, 'Mussolini had no ideas, just rhetoric' (p. 102). It got him a long way-for a while. Kakutani cites a notorious alt-right troll and conspiracy theorist who said in a profile-piece in The New Yorker (Oct. 31, 2116), 'Look, I read postmodern theory in college. If everything is a narrative, then we need alternatives to the dominant narrative ... I don't seem like a guy who reads Lacan, do I?' (p. 46). Everything is not a narrative. The atomic table is not. ${ }^{9}$ Of course we may need 'alternatives to the dominant narrative': But conspiracy theories don't cut the mustard. Kakutani's nicest point is, perhaps this: Putin's quackspeak man is, 'a foremost postmodernist theatre director who has been described as "Putin's Rasputin" and the Kremlin's propaganda puppet master'. (p. 136). Trump seems to know already how to direct his own theatre! Much of it theatre of the absurd. But: It woiks. The base and the Party of Lincoln are infatuated.

\footnotetext{
${ }^{8}$ The Death of Truth by Michiko Kakutani, London, William Collins, 2018. USA ed. Random House/ Penguin (etc.). Ms Kakutani is a Pulitzer Prize-winning literary critic and former chief book critic of the New York Times.

${ }^{9}$ One recalls being told by an otherwise sober philosopher, 'If the Chinese had discovered the atomic table the numbers would be different.' The Chinese calculate to base-10. Different names but the same numbers: Au $\equiv$ Confucium? Possibly.
} 
The alt-right adores him. 'God put Trump in [the] White House: The US ambassador to Israel believes Trump was sent by God...' ${ }^{10}$ The last King of England who ruled by 'Divine Right', Charles I, lost his head — to an axe.

By chance I heard a Trumpism on Australian TV, 'If a second term scares the Democrats, what would twelve terms do with them?' In PoMo, this is an double irony: If twelve terms are impossible, the remark can be laughed off as a joke. However, it may be a serious one: 'If I could get away with it I'm up for it? Double ironies or the ironization of an irony is a PoMo move. An Australian journalist, Chris Uhlmann, wrote, ${ }^{11}$ 'It is not written that Trump will win again, what he may do on the way out is the real horror. Could his last act of his vandalism of American institutions be to burn down the village as he leaves?' He might? As for the twelve terms, Mitch McConnell the poker-faced Republican Senate Leader has had to reassure Americans that if Biden wins, Trump will go. The monstrous storming of the Capitol ${ }^{12}$ put this in doubt. McConnell blames Trump for the attacks, but voted against the second Impeachment! As of December 18, 2020-Joe Biden having been elected President-Trump skulks in the White House refusing to concede. When he goes as go he must in the end, what? As of 24 November, the election of Biden has been officially confirmed. However, Trumpism may well live on. ${ }^{13}$

Trump still has an enormous fascination for his base. Trump is not an ideologue, the Idol is Trump. However, he may finance a 'news' outlet on TV worse than Murdoch's poisonous Fox News. A real ideologue may take up where Trump left offif Trump don't run again - and the USA may be threatened by what the Founding Fathers feared most-a 'mob'. 14

\footnotetext{
${ }_{10}$ Alex Woodward, Independent, New York, Thursday, January 30, 2020, $20: 54$ (online:www.indep endent.co.uk). On PoMo's contempt for science, see The Death of Truth pp. 20, 36-37, 38-39, 43, 75, etc. The present Australian Prime Minister uses the words 'Climate Change' only when he can't avoid them. He favours as a fill-in before solar power, gas. It produces methane, more damaging even than $\mathrm{CO} 2$. There is plenty of sunlight here. Solar panels, please!

${ }^{11}$ The Uhlmann quotes are from his initial piece, The Age, 22 September 2020, and from one by Orietta Guerra in the same newspaper, September 13, 2020, pp. 20, 36, etc.

${ }^{12}$ For a firsthand account see Luke Mogelson, 'The Storm' in The New Yorker, January 25, 2021, pp. 34-53. My memory of hearing Trump on 'twelve terms' is semi-confirmed, p. 43, $\mathrm{col}^{\mathrm{b}}$. If you live in a republic, Mogelson is required reading. The report begins, 'By the end of President Donald Trump's crusade against American Democracy...' The cover of the The New Yorker has the American Eagle carrying off Trump: If only! The second Impeachment voted down, The Donald could still run for public office. The Union could still lose the Second Civil War!

13 The most incisive essay on Trumpism is by Finton O'Toole, in The New York Review, February 25, 2021, 'The Trump Inheritance', pp. 4-8. His analysis is, '...Trump lied prodigiously... his construction of "alternative facts" has deliberately and successfully obliterated fro his supporters the distinction between the fake and the genuine. But pure falsehood alone would not have created the bond between Trump and his base. What he managed to do was simultaneously to erase the distinction between the valid and the bogus and to remake it.' (p.6, $\mathrm{col}^{\mathrm{d}}$ ) By such a dodge a scoundrel might subvert the American Republic. Of America's future, O'Toole writes, ominously: 'The Republican Party is now a wholly owned subsidiary of Trump Inc.' (February 8, 2020 in the Irish Times)

${ }^{14}$ See The Federalist Papers, authored by Alexander Hamilton (c1755-1804), John Madison (17511836), and John Jay (1745-1829), Introduction by Charles R Kessler, Edited by Clinton Rossiter, Signet Classics, Reprint Edition, 2003.
} 
But don't blame Trump for America, blame America for Trump. In 2012, Peter Turchin - a University of Connecticut ecologist, evolutionary biologist, and mathematician-made a prediction that the USA was heading for a chaotic and violent 2020. He says:

The fundamental problems are a dark triad of social maladies: a bloated elite class, with too few elite jobs to go around; declining living standards among the general population; and a government that can't cover its financial positions. ${ }^{15}$

The Decline of the West is not just about the USA, although my private joke, 'The USA is the World's richest failed state' is already a journalists' commonplace. I did not spread it, it 'just growed'.

Uhlmann has rated world leaders according to their success in dealing with COVID-19: 'Watching the world's political class respond to the coronavirus and guide the trajectory of major powers proves the planet is run by imbeciles who really mean it, and worse [by] the truly malevolent.' This would include the UK, and much of the EU. Australia tries hard to cope: New Zealand scores even better.

The title of an essay in Michiko's Kakutani's bibliography fascinates me: Pluckrose, Helen 'How French Intellectuals Ruined the West', Areo, Mar. 27, 2017. Paul de Man and Jacques Derrida have much to answer for.

French intellectuals aside, I leave the last word with Uhlmann. China is Australia's biggest trading partner, the USA our military protector. An anonymous respondent to Uhlmann's article is reported, (in Orietta Guerrera's piece) 'Australia is caught between a pathological narcissist despot wannabe, and a true despot'.

Ms Kakutani could not have foreseen that the 2020 US Presidential Election would result in a victory for a Democratic Party candidate such as Joe Biden. Only a comic dramatist-or a South American Magic Realist novelist-could have imagined the present reality: Voted out, Trump is still refusing to accept the fact. This probably does not surprise Ms Kakutani.

The leaders of the Free World have congratulated President-Elect Biden, as has former President George W Bush, and latterly H.H. Pope Francis, the Chinese government, and President Putin. Trump as of now seems-as do some of his entourage and his numerous base-to remember only the 2002 remark by a then a senior adviser to President George W Bush, '...we create our own reality... ${ }^{16}$ That President simply went graciously when his time was up. Reality is not 'Reality' TV. 'Reality' TV is not reality.

President-Elect Joe Biden and his Vice-President Elect Kamala Harris both used in their victory speeches the words 'truth' and 'science', and 'empathy'. Their plan is to collect a team of scientists to advise on how to cope with COVID-19 which has killed over 300,000 Americans (as at mid-December 2020). Trump ignored the virus — even after he had had it_-'It will go away'. So will he-eventually. But:

\footnotetext{
15 Graeme Wood, 'The Historian Who Sees the Future', The Atlantic, December 2020 Issue. First published online on November 12, 2020, under the heading 'The Next Decade Could Be Even Worse'.

16 Ron Suskind, 'Faith, Certainty and the Presidency of George W. Bush', The New York Times magazine, October 17, 2004.
} 
'Despite all the misleading statements Donald Trump has made, he has never fallen much below 40 percent approval,' Kim Darroch, the former British ambassador to the United States, told me. 'That's pretty solid. What does that tell you? That we're living in a post-truth world. Politicians around the world will be looking at this and saying, 'You can get away with it.' It's a shift in the landscape that may be irreversible.' 17

A post-truth world will be no Utopia, and that's the truth of it.

As for Poland, Hungary, Turkey, Brazil—and some other countries-authoritarian tendencies grow. Even the UK- 'The Mother of Parliaments'-seems unsatisfactory. All authoritarian governments fear and suppress truth. We might make do without God, but without truth? The Jews were lucky that God occasionally manifested His wrath to them: Heaven came down to earth, with a bump. In the Middle Ages, Theology was 'the queen of sciences, because it studied the Highest Being'. Now 'science' means the natural sciences. Nature is a closer object of study than is God. Ergo climate change deniers, anti-vaxxers, etc., are less rational than are people who believe in God. Science is rationality distilled, and its errors are open to correction. Theology, even to believers, has an inherent opacity. I am a dunce in cosmology, viral-research, etc., but believe in the scientific method: Its logical structure is clear. Scientific experiments are perspicuous only to those with appropriate training. And that's a fact. Unfortunately. Politicians without a smidgen of science in their heads can run-if they choose-with the least educated of their constituents. Some do. The anti-COVID facemask so becomes a marker of political opinion: As in the USA.

Against the political fall into the quotidian there are no bombproof shelters, and no Noah's Ark in the great Flood of mendacity. Swim!

\section{I a Stranger and Afraid: In a World I Never Made. A.E. Housman ${ }^{18}$}

The psychoanalyst Adam Phillips writes in hisThe Beast in the Nursery, ${ }^{19}$ 'Why ... hasn't the death of God been the death of our preoccupation with ourselves as lacking? Making a fetish of absence is the last move of a worn-out theology.' If for Hindus nastika amounts to not believing in the Vedas, the death of God may entail the 'West's' rejecting of both the Old and the New Testaments. The people of the sub-continent may have other theologies to fall back on. We have not; not respectable ones. Sceptical-believers in the 'West' told, 'God is dead', may save their belief by borrowing the elegant Indian neti neti and then try the strategy of modern theology—mostly German—of redefining God. 'God is dead!'

17 Peter Nicholas, 'What to Expect Next From Donald Trump', The Atlantic, online, November 8, 2020.

18 Alfred Edward Housman (1859-1936) English poet, classical scholar, and atheist. Quotation from Last Poems, London, Grant and Richards, 1922; USA/New York, Henry Holt, 1922.

19 The Beast in the Nursery by Adam Phillips, London, Faber and Faber 1998, p. 20. (See p. 102 and pp. 113-114.). 
occasions the remark, 'The old descriptions are dead, but not God' ${ }^{20}$ As for feeling that we are lacking, who does not? Even if we do not know quite what it is that we lack, we know we lack it. 'It' remains a '?'. Adam and Eve, Genesis III, were driven out of Eden. There is no way back. Other religions register The Fall in other stories. But what Genesis III marks, other religions must deal with. We_none of us_are 'Happy Campers'. The Australian idiom must have its versions all-over.

The Vedas are older even than the Old Testament: this makes them more venerable. Or so remote in time that the propositions in them may seem to come from a 'form of life'-see Wittgenstein — so remote as to be, or seem to be, now only doubtfully intelligible?

The Jewish Old Testament, although younger than the Vedas, seems to belong to a time before Mythos zum Logos. The first moment in Christianity is The Fall: The eating by Eve and Adam of the apple plucked from the Tree of the Knowledge of Good and Evil. The primal couple were specifically forbidden by God to eat from it.

The Puritan poet John Milton (1608-1674) in his Paradise Lost-in which he hopes 'to justify God's ways to Man'-begins:

Of Man's first disobedience, and the fruit

Of that forbidden tree whose mortal taste

Brought death into the World, and all our woe

With loss of Eden, till one greater Man

Restore us, and regain the blissful seat,

Sing Heav'nly Muse... ${ }^{21}$

The greater Man is Christ who was crucified in Atonement for the primal disobedience - a sin—rose from the dead and He regained 'the blissful seat'. But we are left: left 'preoccupied with ourselves as lacking'. Pace Adam Phillips we do not, 'make a fetish of absence'. If God is dead, we should-perhaps_abandon the once-neat phrases about, 'There is a God shaped hole in the modern mind/worldview', etc. With or without God, The Fall, the Atonement, the Resurrection, we still feel ourselves unprovided for. Sartre's 'Man is a useless passion' ${ }^{22}$ matches one's own feelings. We have the sense of being in want: often in want of something indeterminate.

\footnotetext{
${ }^{20}$ There is a considerable literature on (re)-defining God. A useful book on this is Theology After Liberalism: A Reader, ed. John Webster and George P. Schner, Oxford, Blackwell, 2000. There is a continuous set of 'Blackwell Readings in Modern Theology'.

21 'Malt does more than Milton can / To justify God's ways to man.' A.E. Housman, Last Poems. Malt is of course an essential ingredient in beer and whisky: neither fills up our 'lack' for us. In The New Mistress Housman wrote: 'We for a certainty are not the first / Have sat in taverns when the tempest hurled / Their hopeful plans to emptiness, and cursed / Whatever brute and blackguard made the world.'

22 'Man is a useless passion', L' Etre et le Néant, (Paris 1943) Part 4, Ch. 2, III, Hazel E. Barnes, first English trans., New York, Philosophical Library 1956. There is also, London, Routledge edition, 1956.
} 


\section{Worrying about The Fall: Nastika?}

Chapter III of Genesis gives us the account of The Fall. It is not easy to read it as a literal narrative. Indeed, his present Holiness Pope Francis writes:

The story of Adam and Eve, the rebellion against God described in the Book of Genesis, uses richly imaginative language to explain something that actually happened at the origins of mankind. ${ }^{23}$

The Pope concedes that the story is told - as myths usually are-in 'richly imaginative language'. But he insists that the language is wrapped around 'something that actually happened'. A sceptical believer-they pop up in Sophia from time to time-may look at the myth bit with hermeneutic suspicion. With Nastika? The Genesis Chapter opens with, 'Now the Serpent was more subtle than any beast of the field which the LORD God had made. And he said unto the woman, Yea, hath God said, Ye shall not eat of every tree in the garden.' And he goes on, agent provocateur that he is, to tempt Eve to eat of the very tree that she knows to be forbidden. Who was responsible for hiring a talking snake? Surely not God: almost certainly the imaginative myth writer. And, with due respect to His Holiness, does this whole story explain anything? 'God moves in mysterious ways...' and explanations always fall short. And the nakedness element which follows the primal disobedience seems not to follow directly from the eating of the forbidden fruit. The standard Christian answer to: 'Why, suddenly, fig-leaves?', is that a result of the primal transgression that Adam and Eve lost their primal innocence, and acquired concupiscence, that desire which we all have for things which are as forbidden as the fatal apple: Or, as in the Ten Commandments, 'our neighbour's wife.' See the endless commentary on erotic desire, from innumerable moralists, and-sometimes discordant—-psychologists. Read Freud, and indeed Adam Phillips who is quoted in the present essay.

God displeasure at any person's breaking of any of His Commandments can be illustrated pragmatically: I quote the 'Act of Contrition' which I learned as a boy: 'Oh my God I am heartedly sorry for having offended Thee, and I detest my sins above every other evil, because they displease Thee who for Thy Infinite Goodness, art so deserving of all my love, and by Thy Holy Grace resolve never more to offend Thee, and amended my life. Amen.' The phrases which I have put in Italic open up big questions in Theology and Philosophy of Religion. Is sin somehow worse than every other evil? If so, how? (St John Henry Newman thought it was so.) If God's displeasure defines $\sin$ in ill-conduct does this, or does it not, entail a command theory of value? (The Adam and Eve story seems to.) And is God's Infinite Goodness so perspicuous that we have a sense of it when we do $\mathrm{X}$-known by us to be bad? Each of those questions: (i) can be gone into, (ii) no doubt have already gone into by some Theological writers or some Philosophers, (iii) God's infinite goodness grows from his Necessary Being: if the bad is a mere

\footnotetext{
23 The Name of God is Mercy. A conversation with Andrea Tornielli, trans. Oonagh Stranski, London, Bluebird Books for Life/Pan Macmillan, 2016, p. 42. Italic on 'explain' added. The book is marvellous, clearing away a lot of pre-Vatican II lumber.
} 
absence of $x$, God as Infinite and Necessary lacks nothing, has no absences. This is the view of St Thomas Aquinas, it is too complex to be dealt with here: But see Summa Theologica, Ia, iv.2.

Crucially here does God's Infinite Goodness trump his not sending or arriving-as the Messiah of popular expectation? Are critical points of dissatisfaction with God's world satisfactorily dealt with, Or: does 'Infinite Goodness' quash in advance all of anyone's doubts?

\section{Types of Atheism}

There are at least two sorts of atheism. The first looks at the world as it is - as it usually is - and says, 'If there is a God why does SHE not deal with all this mess?' Atheists of this kind take the acknowledged 'Silence of God' as grounds enough to deny that God exists. This is a reasonable position to take. The inference may be contestable: I shall not contest it here. It is more interesting for our present purposes to look at Wallace Stevens'-quasi-Atheism in our next section. Meanwhile, it is amusing to note that even the Jansenist Pascal would not argue against 'popular atheism', he thought contestation useless. He wrote:

Pensée 542, The metaphysical proofs of God are so remote from the reasoning of men, and so complicated, that they make little impression; and if they should be of service to some, it would be only during the moment that they see such demonstration; but an hour afterwards they fear they have been mistaken. $^{24}$

\section{Wallace Stevens' Quasi-Atheism: The Christian Worldview: Some Candid Remarks about Its Difficulties}

Western Christianity often takes a cheerful, almost Leibnizian view of God's Creation. Samuel Beckett's Waiting for Godot and his numerous novels run counter to happy accounts of the human condition. Existentialists are not often in favour of existence itself. The Jews who met 'our' God before we did would have understood Beckett's deep misgivings. David Benatar in his extraordinary book Better Not to Have Been Born ${ }^{25}$ tells us that, 'The Talmud ... briefly records the subject of a fascinating debate between two famous rabbinic schools - the House of Hillel and the House of Shammi. We are told that they debated the question whether or not it was better for humans to have been created. The House of Hillel, known for lenient and humane views, maintained that it was indeed better that humans were created. The

\footnotetext{
24 Pensées by Blaise Pascal (1623-1662) trans. W.F. Trotter, with an introduction by T.S. Eliot, Oxford, Benediction Classics, 2011, (printed in Australia), p. 172.

25 Better Not to Have Been Born: The Harm of Coming into Existence by David Benatar, Oxford, Clarendon Press, 2006. Benatar reminds us of Sophocles', 'Never to have been born is best...' Oedipus at Colonus, Lines 1224-1231. He reminds us also of Job Ch. 3:24. For the quotations from The Talmud, see Benatar pp. 222-223.
} 
House of Shammi maintained, by contrast that it would have been better had humans not been created.' To this Benatar adds, '... here [in my work] we have a decision in favour of Shammi, (pp. 222-223)'.

The American poet Wallace Stevens might well have favoured Shammi. I cite this from his Esthétique du Mal:

It was almost time for lunch. Pain is human

There were roses in the cool café. His book

Made sure of the most correct catastrophe

Except for us, Vesuvius might consume

In solid fire the utmost earth and know

No pain (ignoring the cocks that crow us up

To die.) This is part of the sublime

From which we shrink. And yet, except for us,

The total past felt nothing when destroyed.

Collected Poetry and Prose, p. 277: Collected Poems, p. 314

(Library of America edition) (Knopf NY/UK, Faber and Faber) ${ }^{26}$

Without human consciousness there would be no human pain. Humankind is a mistake.

The Lord Buddha teaches us to rid ourselves of passions and attachments. If we had not been, there would have been none of these of which to rid ourselves.

Stevens' Esthétique du Mal has an ironic title; aesthetics is concerned with the sublime and the beautiful-Longinus, Edmund Burke, Immanuel Kant-not with pain. $^{27}$ The irony intensifies, since Stevens' life-project was to replace God ${ }^{28}$ with a Supreme Fiction which-he thought-would deaden all the twinges of existence. Existential pain would have an aesthetic palliative. So, in the crucial part of the poem, Stevens - raised a decent Lutheran-writes this of God and Christ, in section III of the poem:

Because we suffer, our oldest parent, peer

Of the populace of the heart, the reddest lord,

Who has gone before us in experience.

If only he would not pity us so much

\footnotetext{
${ }^{26}$ The poem beings 'He was at Naples writing letters home...' qv. The 'he' is Pliny the Younger (61c. $113 \mathrm{CE}$ ) who wrote 'Epistles concerning the eruption of Mount Vesuvius'. This engulfed Pompeii in 79CE. The Collected Poetry and Prose is the Library of America one, ed. Frank Kermode and Joan Richardson, 1977. Stevens' Collected Poems were first published in 1954 by Knopf of New York, NY; there are editions, including paperback ones, published in London, by Faber and Faber. The book which Pliny is-perhaps-reading is Longinus' On the Sublime (c. 213-273 CE) so the lines, 'This is part of the sublime / From which we shrink.'. You can see from the dates that Pliny's reading Longinus would be poetic licence. So, 'His book' is the account of the eruption of Vesuvius which Pliny wrote after it which, 'Made sure of the most correct catastrophe'; that is, recorded it for future generations.

${ }^{27}$ Psychiatrists may agree, or disagree. I write as a layperson.

${ }^{28}$ Stevens, writing to nun, denies that he was an out and out atheist: 'I am not an atheist although I do not believe today in the same God in whom I believed when I was a boy.' Letter 808, to Sister Benetta Quinn in Letters of Wallace Stevens, ed. Holly Stevens, University of California Press, Berkley, 1996.
} 
Weaken our fate, relieve us of woe both great

And small, a constant fellow of destiny,

A too, too human god, self-pity's kin

An uncourageous genesis ... It seems

As if the health of the world might be enough.

CPP p. 278; $C P$ p. 315

Stevens' 'self-pity's kin' is written in an extreme of bitterness. Among humans, self-pity is not esteemed. Was the Atonement gone through with by the Son of God because God was, infinitely, miffed by the sin of Eve and Adam? Should SHE not have just shrugged it off? Was God 'testing humankind to destruction', as the manufacturers of good motorcars do? Perhaps not. Or, are only Saints 'the new and improved model'? There is the nice French saying: 'To understand - fully - is fully to forgive.' An Infinite God-sulking? Just like one of us: 'A too too human God.'

Furthermore: were God liable to ethical judgement by us, might we not regard God (The Father) as needlessly cruel to the Son. If the Atonement was necessary, how much insight may we have to this necessity? Again: might not God-theomniscient have come up with a different and less cruel solution to the problem? In Oxford, I put-some of this-to Anthony Kenny, then still a Catholic priest; his answer was - virtually_ 'It had to be done as it was done'. There is a considerable literature on the subjection of Son to the Father. I have not read it: Fr Kenny probably had. In the Australian liturgy of the Mass, when Christ's death is mentioned, there is an addition, 'To which he freely consented.'

Stevens' 'If only he would not pity us so much', is about God: 'God so loved the world that he sent His only begotten son... ${ }^{29}$ to be crucified, '... a over-human god / Who by sympathy has made himself a man...' is Christ, the Son of God. St Paul writes about Christ crucified: 'Here are the Jews asking for signs and wonders, here are the Greeks intent on their philosophy; but what we preach is Christ crucified: to the Jews a discouragement, to the gentiles mere folly...' (I Corinthians I, Knox trans.). The earlier translations have 'folly to the Greeks'. The readers of Sophia will probably have a little of the Greek in them, and a fair dose of philosophy. Sophia is read by people who would understand why Paul was not keen to discuss 'Christ Crucified' in a Socratic Dialogue with the Greeks, 'intent on their philosophy.' Paul was on a mission-for him, no seminars!

The existential crux is that there were in Christ's time two different ideas about the Messiah:

(1) The optimistic one, that he would come, and with his angels conquer the Romans and establish a Kingdom-one in which there would be universal peace and justice, 'the health of the world', and more.

\footnotetext{
29 John 3:16. The full text reads: Gospel of John 16ff, 'God so loved the world that he gave is only begotten Son, so that those who believe in him may not perish, but have eternal life (17). When God sent his Son into the world, it was not to reject the world, but so that the world might find salvation through him. (18) For the man who believes in him, there is no rejection... (Knox trans.).
} 
(2) Then there was the paradoxical one about the Suffering Servant of Isaiah $53 .{ }^{30}$ Christ was not to be the Saviour of the Jews, driving the Romans out by force: He was not to save us from, 'the poverty of the world' - one of Stevens' recurrent themes-but from sin. The Original, the Primal, Sin, not atoned for would leave us in our own sins and unfit to go into Paradise. Of course, the 'optimistic' Messiah promise would have suited us better. But we were not asked ' 1 or 2?'

\section{The Holy Trinity: Problems of Reference in Stevens' Esthétique du Mal}

Born into a Christian family-Roman Catholic-I do not wish to attack the doctrine of the Atonement. However, en philosophe, I see ways in which it might strike someone of a quite different religion, Hindu, Muslim, Buddhist as, (a) difficult to make sense of, (b) so paradoxical ${ }^{31}$ as to be regarded as a mystery-as it already is for Christians, anyhow. About (a): Why should the Son of God have to atone for the primal sin committed by two-mere-creatures? About (b): What is meant about by the expression 'Son of God'? The doctrine of the Trinity is $(\alpha)$ a dogma, $(\beta)$ 'above but not against reason'. This is a formula puzzling in itself is used to justify intellectual assent by the reasonable to whom what is asserted is above and beyond their reason. A rather circular way of putting a point.

What is meant by 'Son of God'. A diagram may help: The triangle is the Godhead: $\mathrm{F}=$ Father; $\mathrm{S}=$ Son; $\mathrm{HG}=$ the Holy Ghost.

\footnotetext{
${ }^{30}$ Isaiah 53 reads: ... to whom is the arm of the LORD revealed? (2) for he shall grow up before him as a tender plant, and as a root out of a dry ground: he hath no form nor comeliness, and when we shall see him, there is no beauty that we should desire him. (3): He is despised and rejected of men; a man of sorrows, and acquainted with grief; and we hid as it were our faces from him; he was despised, and we esteemed him not (4). Surely, he hath born our griefs, and carried our sorrows; yet, we did esteem him stricken, smitten of God, and afflicted (5). But he was wounded for our transgressions; he was bruised for our transgression; he was bruised for our iniquities; the chastisement of our peace was upon him; and with his stripes we are healed. (AV).

${ }^{31}$ See, Christianity and Paradox: Critical Studies in Twentieth-Century Theology, by Ronald W. Hepburn (1927-2008), London, Watts 1958 and 1966. He ran the Philosophy Department at the University of Edinburgh in the 1970s when I was study leave replacement for Professor W.H. Walsh. Hepburn was keen on a disputed-reading in Timaeus which is about a fall not man's fault. See my 'The Sublime and Kant's Aesthetic Ideas: Excess the Nexus?' An Excess of Excess's Even? Need the idea of God be only an Aesthetic Idea? Or Not Even That?' in Literature \& Aesthetics, 29 (1) 2109; pp. 499-140. https:// openjournals.library.sydney.edu.au/index.php/LA/article/view/13415

In my long footnote 12, pp. 123-124 the, contested, reading of Timaeus $30^{\mathrm{a}} 53^{\mathrm{b}}$ goes thus, 'the Receptacle was recalcitrant'. When the Demiurge tried to order it by dropping into it the five regular solidswhich the Greeks understood - the Receptacle resisted the attempt by the Demiurge to produce a World, rational through and through, failed. This was a fall, if not a moral one. Hepburn had intended to take Holy Orders in the Presbyterian Church, but did not. I suspected a fall not caused by humankind-our Fall-had for him an aesthetic or moral attraction. I felt that this was the case, but I refrained from putting the question. I now wish I had.
} 


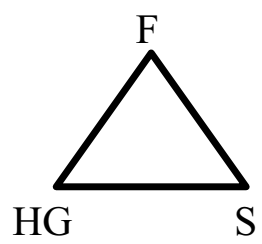

If $\mathrm{S}$ is to be crucified to Atone for the primal sin-by becoming Himself manthen is this a blood offering to $\mathrm{F}$ and HG? Or is it to $\Delta$, in which case is $\mathrm{S}$ sacrificing Himself to Himself ?-even'tho he was crucified as man-who had emptied himself of God-being.

The early Church, Fathers of the Church, Councils of the Church, and ordinary believers puzzled and argued about the puzzle $\Delta^{32}$ and the puzzle within a puzzle, i.e., was $\mathrm{S}$ in $\Delta$ when crucified? Did God sacrifice Himself to Himself? I have neither the space nor the theological learning to write about the various official unpuzzlings of the puzzle or the puzzle within the puzzle. The reason I bring all this up is not just so that Hindus, Buddhists, Shintoists can out-argue missionaries-though en philosophe I lend them any part of this that they feel that they need-but because it shows how the problems of specific reference in the crucial section of Esthétique $d u$ Mal arise rather from the subject matter of Stevens' poem-at this point-and not just from his usual use of obscure language and tropes. Stevens was a Lutheran, and Lutherans are good at theology, so Stevens' obscurity is understandable. Appropriate, even. That he converted to Roman Catholicism on his deathbed, 'Amazing Grace'.

Once it might have been seen as blasphemous to raise the question, 'Was the Father cruel to the Son?' During the revelations to a Royal Commission into paedophilia in the Catholic - and other-Churches, The Age (Melbourne) ran a cartoon: Beside an over life size crucifix stands a-Roman-prelate, and a scruffy little boy. Throwing the Bible behind him, the Bishop says, 'Let's us not dwell too much on who did what to whose son.' (The Age, 4 March 2019, p. 23). There was no public outcry.

One marvellous Parish Priest-now retired-made the cartoonist's point more seriously, more properly. At Christmas, he bought a new sapling, and decorated it. On Good Friday, there was a Scots piper playing a lament, and a layman entered with a chainsaw and cut the tree to make of it a cross.

To the Crucifixion of Christ, as to the two possible Messiahs, there are two possible attitudes, the high-toned orthodox one, and the vulgar, popular one. The vulgar one is a heterodox, but anyone can see why the very simple-minded might take it.

\footnotetext{
32 For a classic and readable account of, (1) Mystery, (2) The definition of the Trinity see: Belief in the Trinity, by Dom Mark Pontifex, Monk of Downside, London, Longmans Green, 1954.
} 
Simple-mindedness might even have a momentary appeal to the-weary-orthodox. The high-toned attitude was taken by St Augustine of Hippo (354-430) who wrote:

Oh happy fault that earned for us

so great, so glorious a Redeemer.

$O$ felix culpa quae talem et tantum

meruit habere redemptorem. ${ }^{33}$

The vulgar attitude I heard as an Easter carol in an Anglican Cathedral:

'Twas all for an apple, an apple that they took

As clerkēs finden

Written in a Bōōke!

'Why', the Vulgar ask; 'Did God find it such an important fault?' 'A mere apple!' (I have always objected, 'Adam and Eve had no remit from me!').

Why this damned inheritance? And how? St Augustine answers the second question, 'Through the sexual intercourse of your parents.' He would. See his Confessions. Augustine's Confessions are generally reckoned the first autobiography of the-late-Classical period: They describe his ascent from energetic sinner tosevere-saint. The technical term 'Original Sin' is ascribed to him. Of the rankness of its consequences for us, Stevens writes:

That evil, that evil in the self, from which

In desperate hallow, rugged gesture, fault

Falls out on everything: the genius of

The mind, which is our being, wrong and wrong,

The genius of the body, which is our world,

Spent in the false engagements of the mind.

Esthétique Du Mal, IV, CPP, p. 729; CP pp. 316-317

Bad Karma is the universal inheritance of humankind.

The opacity of much that the Christian religion's doctrine-its 'resolving' into Mystery-reminds me of a passage in the Metaphysical Poet Henry Vaughan (1621-1695): The Night. $^{34}$

There is in God (some say)

\footnotetext{
${ }_{33}$ Augustine, St (Bishop of Hippo), Enchiridion on Faith, Hope and Love, Introduction by Thomas S. Hibbs, Gateway Editions, Reprint Edition, 1996. See also St Augustine Enchiridion-viii-and St Thomas Aquinas Summa Theologica III 13 ad 3.

${ }^{34}$ Henry Vaughan: The Night may be found in Vaughan's Sacred Poems, ed. The Rev. H.F. Lyte, London, George Bell and Sons, 1883, p. 211. The Oxford Book of Seventeenth Century Verse, Sir Herbert Grierson and G. Bullough Oxford, Clarendon Press, 1934 (often reprinted) pp.785-787. The Night is not in Metaphysical Lyrics \& Poems of the Seventeenth Century: Donne to Butler, ed. Herbert J.C. Grierson, Oxford, Clarendon Press, 1921. Eight Metaphysical Poets, ed. Jack Dalglish, London, Heinemann Educational Books, 1961 (often reprinted) pp. 86-87. For readers not well versed in Metaphysical Poetry, this edition has an excellent Introduction and notes. Vaughan wrote in The World perhaps the most stunning line in seventeenth century poetry, 'I saw Eternity the other night...' op. cit. pp. 81-82. There is also a Penguin edition, 1995.
} 
A deep but dazzling darkness; As men here

Say it is late and dusty, because they

See not all clear;

$\mathrm{O}$ for that night! where I in him

Might live invisible and dim.

Metaphysical poetry, written by believers, is shot through with various doubts-

... because they

see not all clear

while acknowledging 'a deep but dazzling darkness'. The two words dazzling and darkness are in tension, if not, quite, in contradiction. God seen would be dazzling - and the poet would have regarded this as a commonplace. Unseen, God leaves the writer in deep darkness, because He does not appear, even to this believer. The notion of the darkness of God is trivalent: (i) Because I cannot see or understand, I doubt that there is a God. (ii) God keeps us in the dark about so much, I am, though I believe, unhappy to find God less forthcoming than I would like. (iii) I am a mystic: but my experiences are not Illuminations. What I find is the darkness of God. So (iii) cancels (i); has affinities-of a sort-with (ii) but itself not quite what I had expected or hoped for. The darkness of God sometimes affects even mystics, in a negative way as the kernel of an-expectedly-positive-experience. ${ }^{35}$

The Night is referenced John III 2 which gives an account of Nicodemus-a member of the Jewish establishment—visiting Jesus by night. So ' $O$ for that night! where I in Him might live invisible and dim'. Close to Christ, Vaughan would be dim in the-positive-dazzle of the Risen Lord. Nicodemus met Christ before the Crucifixion, and provided Him a tomb.

\section{Samuel Taylor Coleridge: The Kernel of Religion}

In an entry in Coleridge's Table Talk ${ }^{36}$ for October 15,1833 , he gives us the kernel of the Christian religion:

The Trinity is the idea: The incarnation, which implies the Fall, is the fact: the Redemption is the mesothesis of the two - that is - the religion (p. 278).

Coleridge's 'implies' here in the twenty-first century English reads oddly. The Fall is the necessary and sufficient condition of both the Incarnation and the Redemption. The Fall is the crucial event in the Christian story: It made a mess of 'the fall into the quotidian', and it swirls like a vortex still, despite the Redemption. There is no hope whatever of returning to a Prelapsarian Eden.

\footnotetext{
35 The Darkness of God: Negativity in Christian Mysticism by Denys Turner, Cambridge, Cambridge University Press, 1995, pb edn. 1998.

36 Specimens of the Table Talk of Samuel Taylor Coleridge, ed. H[entry] N[elson] C[oleridge] second edition London, John Murray, Albermarle Street MDCCCXXXVI (1836) P.275. 'Mesothesis' = mediating agency or principle'.
} 
Furthermore, because of The Fall, we all got born with some bad Karma. For Coleridge, the Fall was both a past event and a personal matter. In his extensive Prolegomena to Coleridge's Opus Maximum, ${ }^{37}$ Professor McFarland notes Coleridge's sense of sin. We inherit 'Original Sin' and so we are prone to sin, ourselves which leads to S.T.C's fatal flaw: 'Coleridge's inability to work at self-assigned tasks was devastating and his opium addiction filled him with self-loathing.' Opium was freely available in Coleridge's day; he began taking it to relieve, according to many accounts, facial neuralgia. He got hooked. So he repented-but could not reverse-his own-personal- fall $^{38}$

There are two passages in the Opus Maximum ${ }^{39}$ which help us see what the sometime Unitarian ${ }^{40}$ made of the religious orthodoxy of the Anglican Church:

'I profess a deep conviction that Man was and is a fallen Creature, not by accidents of bodily constitution, or any other cause, which human Wisdom in a course of ages might be supposed to be capable of removing; but diseased in his Will. ${ }^{41}$ And on the same page, there is this: 'My Faith is simply this - that there is an original corruption in our nature, from which and from the consequences we may be redeemed by Christ ... and this I believe - not because I understand it, but because I feel, that it is not only suitable to, but needful for my nature'. Here, 'feel' has something of the Romantic sentiment to it. Coleridge, although he aimed to construct a full metaphysical system, ${ }^{42}$ was not a Roman Catholic who_-like St Thomas Aquinas (whom he had read) — and who wished to rationalize, Aristotelianize, Revelation: Coleridge was a Protestant to whom the inner feeling of God-with-me, needed no totally external justification.

There is for any Christian one crucial fact, and this-of course-Coleridge acknowledged: St Paul: 'If the dead, I say, do not rise, Christ has not risen either; and if Christ is not risen, all your faith is a delusion...' (I Corinthians, 15: 16-17, Knox trans.)

If the Christian religion was the consequence of a-dateless-Fall recounted in rather mythological language, it depends on a fact which occurred during the Roman occupation of Palestine: The Crucifixion of Christ and the Resurrection of Christ.

Was the Resurrection a fact? One of Jesus' disciples, Doubting Thomas, doubted. St John's Gospel records: 'Jesus came and stood there in their midst; Peace be upon

\footnotetext{
37 Opus Maximum, ed. Thomas McFarland, Vol. 15 in The Collected Works of Samuel Taylor Coleridge, Princeton University Press, 2002.

38 Op. cit. $X V$ Problem and Motive pp. cxii-cxiii.

39 Opus Maximum, Index; xciii; xcivi-ii, 234 n7, 347. S.T.C. read the Upanishads, see pp. 282 n, 202. McFarland was assisted by Nicholas Halmi in connection with these passages. There is much in $O M$ which might interest Indian scholars. S.T.C. refers even to Tibetan theology.

40 Unitarians did not believe in The Trinity; they tried to read the New Testament in purely monotheistic terms.

41 OM, loc. cit., cxiii. What 'Will' means in Western metaphysics we cannot go into here; it is a function both of humankind and of an Absolute on Ultimate being.

42 Coleridge never quite gave up on the Idea of his time that Philosophy and the Natural Sciences could be boxed up together. 'The Fall of Man [can] be shown to be a Necessary Postulate of Science...' $O M$, $X I I I$, Transformations, p. cii $q v$. This despite his having a keen interest in the Science of his day. See, 'Coleridge: A Bridge Between Science and Poetry', by Kathleen Coburn in Coleridge's Variety: Bicentenary Studies, ed. John Beer, London, Macmillan, 1974, pp. 81-100.
} 
you he said. Then he said to Thomas, Let me have thy finger; put it into my side. Cease thy doubting and believe. Thomas answered, thou art my lord and my God. And Jesus said to him, Thou hast learned to believe, Thomas, because thou hast seen me. Blessed are those who have not seen, and yet have learned to believe'. (John 20: 27-30, Knox trans.). Thomas was an empiricist. The Resurrection was a one-off event. So: Faith must replace our modern scientific method: Thomas' experiment cannot be replicated.

If you do not wish to take part in the human predicament, to enjoy/endure eternal life, or cycles of rebirth, do not get born in the first place. David Benatar's The Human Predicament: A Candid Guide to Life's Biggest Questions ${ }^{43}$ is not a self-help book; it contains no practical hints on how to un-be, by never having been.

\section{Is God After You, Like It or Not?}

The philosopher and poet Jean Wahl elegantly suggests it:

L' athée est bien plus étroitment uni à Dieu par son refus où Dieu s'affirme lui même

Que le croyant par sa croyance.

The atheist is even more united to God

By his refusal in which God, affirms himself

Than the believer through his belief.

Poems, $1945^{44}$

This is beautifully put, but is it true?

\section{The Prosperity Gospel}

In many parts of the world, including in Australia, there are mega churches, ${ }^{45}$ which began in the USA, and which encourage their flocks to pray for worldly goods and money. It is difficult to find any Gospel sayings which would authorize this. Christ memorably said, in Matthew 6:19:

'Lay not up for yourselves treasures upon earth, where moth and rust doth corrupt, ...'(AV)

$\mathrm{XxX}$

\footnotetext{
43 Oxford University Press, Clarendon, 2017.

44 Human Existence and Transcendence, by Jean Wahl, trans. and ed. William C. Hackett with Jeffry Hanson. Foreword by Kevin Hart, Indiana, University of Notre Dame Press, 2016, p. xxxii.

45 See Jia Tolentino, 'Ecstasy: Losing Religion and Doing Drugs in Houston', The New Yorker, May

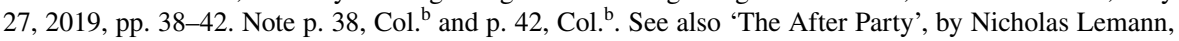
'Nearly twenty years ago, [Trump] formed a public relationship with Paula White, a popular televangelist who preaches the "prosperity Gospel," and who has said that she guided Trump towards active Christianity,' in The New Yorker, November 2, 2020, p. 60, Col. ${ }^{\text {. }}$
} 
As an undergraduate, I used to pray to St Jude who aids hopeless cases: writing this paper, I paid my respects to an image of Ganesh. In Japan, Shinto shrines sell small wooden tablets on which people ask for a blessing - a child, to pass an exam, to find a partner. And so on. We might be living without God, but such practices are probably universal. Pious superstition and folk-belief bear witness to lacks that God might make good: or if there is no God, these are hallowed reminiscences of HIR.

\section{References}

Aquinas, S. T. (1911). The "Summa Theologica", Literally translated by Fathers of the English Dominican Province. Burns Oates \& Washbourne Ltd., Ia, iv, 2.

Augustine, St. (1996). (Bishop of Hippo), Enchiridion on faith, hope and love, Introduction by Thomas $S$. Hibbs, Gateway Editions, Reprint Edition.

Bellow, S. (1964). Herzog. Weidenfeld and Nicholson, [USA ed. 1961].

Benatar, D. (2006). Better never to have been: The harm of coming into existence. Clarendon.

Benatar, D. (2017). The human predicament: A candid guide to life's biggest questions. Clarendon.

Coleridge, S. T. (2002). Thomas McFarland ed, The collected works, Volume 15: Opus Maximum, Princeton University Press.

Coleridge, S. T. (n.d.). Table talk, any edition.

Danner, M. (2020). 'The Con He Rode In On', The New York Review, pp. 35-37.

Ferrante, E. (2019) Incidental Inventions, 'The End', trans. Ann Goldstein, Europa Editions, pp.19-20.

Fink, L. (2020). Cartoon of God, The New Yorker, p. 25.

Francis. (2016). His Holiness The Pope, The name of God is mercy.

Guerra, O. (2020). The age, p. 36.

Hamilton, A. (c1755-1804), Madison, J. (1751-1836), and Jay, J. (1745-1829). (2003). The federalist papers, Introduction by Charles R Kessler, Edited by Clinton Rossiter, Signet Classics, Reprint Edition.

Hepburn, R. (1958). Christianity and paradox: Critical studies in twentieth-century theology, 1966.

Housman, A. E. (1922). Last poems. Grant and Richards. Henry Holt.

Hutchings, P. Æ. (1972). Kant on absolute value. Allen and Unwin.

Isaiah. (1928). Book of The Holy Bible, (AV). Collins.

John. (1945). St Gospel of The Holy Bible, (AV): Knox, Ronald, trans. The New Testament. Burns Oates and Washbourne.

Kakutani, M. (2018). The death of truth. Random House.

Kant, I. (n.d.). The groundwork of the metaphysic of morals, any edition.

Lemann, N. (2020). 'The after-party', The New Yorker, p.60, Col. '.

Mackellar, D. (1885-1968), The poems of Dorothea Mackeller. Rigby, 1971.

Mill, J. S. (1806-1873). Utilitariansim, any edition.

Milton, J. (1608-1674). Paradise lost, any edition.

Mogelson, L. (2021, January 25). The storm. The New Yorker, pp. 5-12.

Nicholas, P. (2020). 'What to expect from Donald Trump', The Atlantic, online.

O'Toole, F. (2021, February 25). The Trump inheritance. The New York Review, pp. 4-8.

Pascal, B. (1623-1662). Pensées: No.542. Any edition.

Paul. (1945). St Gospels, trans. Mgr. Ronald Knox. Burns Oates and Washbourne, often reprinted.

Phillips, A. (1998). The beast in the nursery. Faber and Faber.

Pontifex, D. M. (1954). Belief in the trinity. Longmans and Green.

Sartre, J.-P. (1956). Being and nothingness, trans. Hazel E. Barnes, Philosophical Library.

Stevens, W. (1954). Collected poems, Knopf. Faber \& Faber, 1955. (Numerous reprints).

Stevens, W. (1879-1955), Collected poetry and prose, Library of America Edition, ed. Kermode and Richardson, 1997.

Stevens, W. (1996). Letters, ed. Holly Stevens, University of California Press.

Suskind, R. (2004). 'Faith, certainty and the presidency of George W. Bush', The New York Times Magazine. 
The Holy Bible. (1928). Authorized Version, Glasgow. Etc.

Tolentino, J. (2019). 'ECSTASY: Losing religion and doing drugs in Houston', The New Yorker, pp. $38-45$.

Turner, D. (1995). The darkness of God: Negativity in Christian mysticism, Cambridge University Press. Uhlmann, C. (2020). The age.

Vaughn, H. (1627-1695), The complete poems, ed. Alan Rudrum, Penguin Books Ltd, 1995.

Wahl, J. (2016). trans. W. C. Hackett, Human existence and transcendence, University of Notre Dame Press.

Webster, J., and Schner, G. P. (eds.). Theology after liberalism: A reader. Blackwell.

Wood, G. (2020). 'The historian who sees the future', The Atlantic, Print Edition.

Woodward, A. (2020). Independent, Thursday, 20:54 (online: www.independent.co.uk).

Publisher's Note Springer Nature remains neutral with regard to jurisdictional claims in published maps and institutional affiliations. 